UDC: 378.57 .08

DOI: https://doi.org/10.24195/2414-4665-2017-8-19

\author{
PhD (Candidate of Biological Sciences), associate professor, professor, \\ Department of Medico-Biological and Valeological Bases of Life Safety and Health, \\ National Dragomanov Pedagogical University, \\ 9, Pyrohova Str., Kyiv, Ukraine \\ Valerii Plisko, \\ Doctor of Pedagogy, professor, Department of Pedagogy, \\ Psychology and Methods of Physical Education, \\ Chernihiv National T.G. Shevchenko Pedagogical University, \\ 53, Hetmana Polubotka Str., Chernihiv, Ukraine, \\ Anna Baliuk, \\ post-graduate student, Department of Pedagogy, \\ head of Information and Publishing Center, \\ South Ukrainian National Pedagogical University named after K. D. Ushynsky, \\ 26, Staroportofrankivska Str., Odesa, Ukraine,
}

\title{
WAYS OF SELECTING TALENTED MASTER-DEGREE STUDENTS FOR RESEARCH WORK
}

The paper deals with the issue of evaluation and assessment of university students' research skills. The reason of insufficient development of these qualities is the absence of efficient teaching methods contributing to the transformation of acquired knowledge to the skills of carrying out research activities according to the curriculum. Based on the students' behavior characteristics the technique for the development of research skills has been designed, implemented into the educational process and experimentally checked. In the process of assessing the students' cognitive abilities the differential approach was applied which helped to select the students to deal with research work.

Keywords: research activity, creativity, students, assessment, development.

\section{Introduction}

The reforming of the system of higher education requires universities to train future professionals who will be able to solve tasks creatively, understand and address challenges of their work in the future. One of the promising directions of training is not only the development of students' research skills but also finding the ways of assessing them and selecting students for research work in terms of higher educational institutions. Especially it concerns Master-degree students as they are first of all considered as future researchers working on their theses.

According to the Law of Ukraine "On Higher Education", the curriculum of Master-degree students of any field of study includes research work to the extent of not less than $30 \%$. Taking this fact into account it is obvious that not every student is capable of research activities, which is why it is so important not only to assess their research skills, motivate them for research work but also select talented Master-degree students for it in order to provide them with profound training in this field.

Research activity is defined by creative approaches. Many scientists consider creativity as an integrative and core component of culture. A creative personality is characterized by risk appetite, independent and critical thinking, cognitive interest, initiative, etc. These qualities are considered to be extremely significant in research activity [6].
We believe that there is a lack of pedagogical conditions for research activities in the educational process of modern higher educational institutions. There is a need for addressing a number of challenges: meeting demands of modern educational institutions for highly qualified teaching staff, providing the development of students' profession-related skills, developing pedagogical tools for this process fulfillment [4].

Research means and tools relate to a great number of unpredicted unique situations dealing with which requires constant control, regulation and correction, which demands future professionals to manifest innovative style of analytical thinking [3].

Considering the peculiarities of research activity, logic conditioning and sequence of actions and operations for its performance, one can distinguish the following binary groups of tasks on the development of Masterdegree students' research skills: analytical and reflexive tasks of analysis and reflection of complex research process and its elements using knowledge and skills, including value orientations, difficulties arising, etc.; constructive and prognostic - tasks of building the integral research process by means of selecting means and tools according to general aim; making pedagogical decisions, predicting results and consequences of technological and pedagogical decisions; organizational and activity - tasks of fulfillment of optimal variants of the research process together with the variety of pedagogical activity types; 
assessment and informational tasks - pedagogical, professional, subject; as well as working with and storing information about the state and prospects of the pedagogical system development, and its objective assessment.

The components of research skills assessment involve psychological factors characterizing the level of activeness, as well as the factor of open-mindedness and focus on the achievement of a certain result.

Pedagogical observation of the process of future professionals' training, analysis of the efficiency of their activities have shown the insufficient level of the maturity of their research skills. Besides, modern education is not focused on the development of research skills and motivation for this kind of activities. One of the reasons of the absence of efficient teaching methods contributing to the transformation of acquired knowledge to the skills of carrying out research activities within a discipline [3].

According to some scientists [7] almost in $80 \%$ of first-year students and $20 \%$ of senior university students one can observe immature need for reflexive analysis of operational and processual nature of research activity. About $22 \%$ demonstrate slight reflexive skills, immature desire to self-development and transformations.

Besides, it should be noted that the evaluation of research skills in the educational process is performed at the superficial level, which covers just introduction along with insufficient methodical support.

There are some types of tests helping to select Master-degree students for research work (for example, [1]). Though we believe that is a necessity of assessing future experts according to their achievement motivation, their knowledge and skills of using various means, tools and techniques of organization and management of researches as well as to find and use data obtained as a result of the carried out research, in order to develop and improve curricula, etc. [5].

The paper aims to present ways of evaluating Master-degree students' research skills for selecting them for further research work in terms of higher education.

Tasks: 1) distinguish challenges in the process of future experts' research skills development; 2) describe a technique of evaluation and developing students' research skills, 3) present the results of the experiment aimed at checking its efficiency.

\section{Research Methods}

The evaluation of Master-degree students' research skills is suggested to carry out according to the technique based on the following three methods: method of direct influence, Delphi method (expert evaluation), and feedback.

The method of direct influence makes it possible to assess Master-degree students' activities and motivation for research work during the lesson when presenting a new topic.

Delphi method provides testing in order to assess students' skills of using bonds of every chosen character- istics with other ones. The testing included 21 questions according to the topic of the lesson. Students themselves can act like experts - everyone evaluates a number of comparisons of characteristics by other students without knowing their names.

The third method provides testing considering feedback when evaluating, which means that the emphasis is placed on wrong replies. The students' answers are assessed by the experts accounting for the number of mistakes. When the tasks are reduplicated the number of the mistakes made by the same students is evaluated. Accordingly, the students who made the greatest number of mistakes are eliminated from the rating.

The carried out analysis has made it possible to systematize main directions and tasks of educational and research process in the common field of knowledge, skills formation and present the directions of learning material acquisition by students (fig. 1)

The experiment involved 58 master-degree students who were divided into control $(\mathrm{n}=30)$ and experimental $(n=28)$ groups. We implemented the experimental technique into the curriculum of EG participants, while CG students were taught in a usual way.

The experiment was carried out in three stages. At the first one we examined the respondents' motivation for research work. We evaluated their activeness: a number of questions set, suggestions given, etc. besides, we paid special attention to the manifestation of independent work skills. We distinguished the following criteria: initiative, creativity, algorithm of actions, rationality, correctness of answers and comments.

The assessment of their activeness was performed using a scale. High activeness level (number of questions, clearness of statements, skills of holding discussion, independency) was assessed in 5 scores, imitation of activeness (inconsistent, partial manifestation of activeness) - 3 scores, low activeness (lack of independency, passiveness) - 1 score.

The determination of sufficient level of Masterdegree students' research skills in combination of some characteristics of actions with other ones as well as abilities to perform tasks was carried out according to the scale with further interpretation in percentages.

The examination of the efficiency of the designed technique involved mathematical processing of the testing results before and after its approbation.

At the second stage of the experiment we used Delphi method which was aimed at assessing students' skills of revealing stochastic connectivity between characteristics. In other words, they built logical chain of characteristics and attributes considering a certain action. This method was based on students' knowledge and logical thinking skills.

The third stage presupposed the application of feedback method and was based on involving experts' conclusions. 


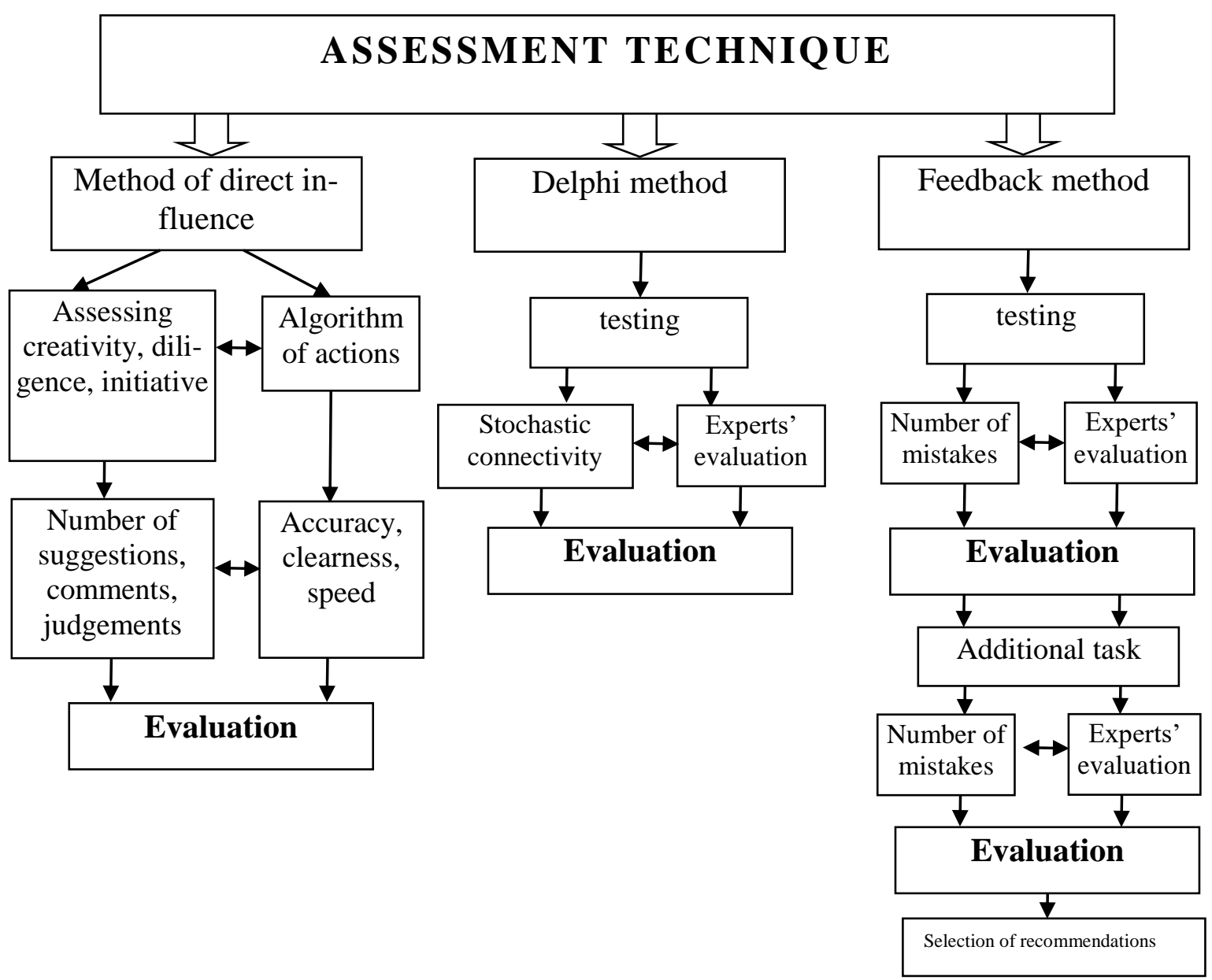

Fig. 1. Technological process of assessing students' research skills

\section{Research Results}

Table 1 presents the dynamics of the respondents' activeness (diligence) before and after the experiment.

Table 1.

The dynamics of the EG and CG participants' activeness (diligence) before and after the experiment, scores

\begin{tabular}{|c|c|c|c|c|c|c|c|c|}
\hline \multirow{3}{*}{$\begin{array}{c}\text { Characteristics } \\
\text { examined }\end{array}$} & \multicolumn{4}{|c|}{ Before the experiment } & \multicolumn{4}{|c|}{ After the experiment } \\
\hline & \multirow{2}{*}{$\begin{array}{c}E G(n=28) \\
\overline{X \pm m}\end{array}$} & \multirow{2}{*}{$\begin{array}{c}\begin{array}{c}\mathrm{CG} \\
(\mathrm{n}=30)\end{array} \\
\overline{\mathrm{X} \pm \mathrm{m}}\end{array}$} & \multicolumn{2}{|c|}{$\begin{array}{c}\text { Statistical } \\
\text { significance }\end{array}$} & \multirow{2}{*}{$\begin{array}{c}E G(n=28) \\
-X \pm m\end{array}$} & \multirow{2}{*}{$\begin{array}{c}\mathrm{CG}(\mathrm{n}=30) \\
-\mathrm{X} \pm \mathrm{m}\end{array}$} & \multicolumn{2}{|c|}{$\begin{array}{c}\text { Statistical } \\
\text { significance }\end{array}$} \\
\hline & & & $\mathrm{t}$ & $\mathrm{P}$ & & & $\mathrm{t}$ & $\mathrm{P}$ \\
\hline Activeness & $2.57 \pm 0.24$ & $2.4 \pm 0.2$ & 0.52 & $>0.05$ & $3.5 \pm 0.29$ & $2.46 \pm 0.26$ & 2.62 & $<0.05$ \\
\hline
\end{tabular}

The research outcomes show insufficient statistical significance of indicators of the respondents' activeness (diligence) ( $>>0.05)$ before implementing the suggested technique. We have found that $10.7 \%$ of the students have high level of activeness, $57.2 \%$ of the respondents simulated activeness, and $32.1 \%$ have low activeness in the EG, and $67.7 \%, 56.7 \%$, and $36.6 \%$ in the CG respectively. The mean value for EG students was $2.57 \pm 0.24$ scores, and for CG respondents $-2.4 \pm 0.2(\mathrm{p}>0.05)$.

The analysis of the research outcomes has shown significant difference $(\mathrm{p}<0.05)$ between EG and CG results after implementing the designed technique at the end of the experiment.

The number of EG students with the low level of activeness has increased by $167.3 \%$ and reached $28.6 \%$; the number of those who imitate activeness has decreased by 
$12.6 \%$ and become $50 \%$; and the number of the respondents with the low level of activeness has decreased by $33.3 \%$ and become $21.4 \%$.

The number of CG participants with the low level of activeness has increased by $49.3 \%$ and reached $10 \%$. The number of the students imitating their activeness has decreased by $6 \%$ which made $53.3 \%$; and there has been found $36.7 \%$ of those with the low level of activeness in the $\mathrm{CG}$.

In general, activeness of the students of EG after the experiment was $3.5 \pm 0.29$ scores, and $C G-2.46 \pm 0.26$ scores $(\mathrm{p}<0.05)($ table 1.)

In technical execution we assessed the algorithm of actions (accuracy, time spent for an action, speed, creativity). According to the results, only $23.3 \%$ of the students have succeeded in it. They are characterized by serious responsible attitude to the performance of tasks, as well as high activeness level.

In the CG only $10 \%$ of the respondents can perform research work independently without teacher's assistance and control.

The dynamics of the development of research skills in EG and $\mathrm{CG}$ accounting for the number, consequence, accuracy of actions during the experiment are presented in Table 2 .

The dynamics of the development of research skills in EG and CG, \%

\begin{tabular}{|c|c|c|c|c|c|c|}
\hline \multirow{2}{*}{$\begin{array}{c}\text { Characteristics exam- } \\
\text { ined }\end{array}$} & \multicolumn{2}{|c|}{ Before the experiment } & \multicolumn{2}{|c|}{ After the experiment } & \multicolumn{2}{c|}{ Success increase } \\
\cline { 2 - 7 } & EG (n=28) & CG (n=30) & EG (n=28) & CG (n=30) & EG (n=28) & CG (n=30) \\
\hline $\begin{array}{c}\text { Sufficient level of } \\
\text { research skills }\end{array}$ & 10.3 & 10 & 48.3 & 23.3 & 368.9 & 133 \\
\hline
\end{tabular}

The analysis of the results of the carried out testing shows that the students of EG and CG had almost equal level of research skills at the beginning of the experiment before implementing the suggested technique. The number of EG students with sufficient level of research skills was $10.3 \%$, and CG students $-13.88 \%$. At the end of the experiment this number increased and became $48.3 \%$ in the EG and $23.3 \%$ in the CG.

The third stage involved the application of feedback method, which was based on experts' evaluation analysis.

According to the experts' opinion, there were $28.6 \%$ of the respondents who have made the greatest number of mistakes when making tests. Besides, their opinion coincided concerning the $2^{\text {nd }}$ and $3^{\text {rd }}$ places in the ranking, other opinions did not correlate with the indices.

We processed, analyzed, and generalized the experts' answers and let them reconsider and specify them. The students making the same mistakes for may times, were eliminated from the rating $(21.4 \%$ of the respondents of EG). Accordingly, it confirmed our opinion that they could not be considered as capable of research work.

The assessment of the respondents' skills when working on the same tasks provided testing. The results are presented in Table 3 .

Table 3.

\begin{tabular}{|c|c|c|c|c|c|c|}
\hline \multirow{2}{*}{$\begin{array}{c}\text { Characteristics exam- } \\
\text { ined }\end{array}$} & \multicolumn{2}{|c|}{ Before the experiment } & \multicolumn{2}{|c|}{ After the experiment } & \multicolumn{2}{|c|}{ Success increase } \\
\hline & $\mathrm{EG}(\mathrm{n}=28)$ & $C G(n=30)$ & $\mathrm{EG}(\mathrm{n}=28)$ & $\mathrm{CG}(\mathrm{n}=30)$ & $\mathrm{EG}(\mathrm{n}=28)$ & $\mathrm{CG}(\mathrm{n}=30)$ \\
\hline $\begin{array}{l}\text { Sufficient level of } \\
\text { research skills }\end{array}$ & 10.7 & 6.7 & 32.1 & 13.8 & 200 & 105.9 \\
\hline
\end{tabular}

It should be noted that the most common errors made by students were as follows: when making hypotheses the respondents did not take into account some aspects contradicting them; they could not distinguish the main and accessory things, they had a tendency of making premature conclusions.

The research outcomes prove the effectiveness of the suggested technique. The number of the CG participants with the medium level of research skills was $6.7 \%$ at the beginning of the experiment, and increased up to $13.8 \%$ at the end of the carried out research; $10.7 \%$ and $28.6 \%$ respectively in EG.

The implemented methods of differentiated assess- ment have greatly increased the efficiency of the educational process. At the beginning of the experiment more that $82 \%$ of the respondents of the EG were indifferent to the research work, though at the end their interest considerably increased, the number of indifferent persons decreased up to $42.9 \%$.

As a result of the carried out experiment we have selected 15 Master-degree students who have highly developed research skills and interviewed them concerning the issue of their desire of working and self-development in this area. According to the interviewing outcomes, we have concluded that 10 of them can be recommended for further training in this field. 
Besides the advantage of the suggested technique is that students' research skills can be assessed separately by every method or in combination gradually applying them.

\section{Conclusion}

The carried out research has helped us to find the reasons of students' immature research skills. Based on the study of students' behavior characteristics, their knowledge and skills, we have designed a technique of differentiated assessment of future experts' research skills development.

The suggested model provides the use of direct influence, expert evaluation (Delphi method), and feedback method which can be applied either separately or in combination. The gradual implementation of these methods

\section{REFERENCES}

1.Artemchuk, G.I., Kurilo, V.M., Kochergan, P.M. (2000). Metodyka organizatsii naukovo-doslidnoi roboti: navch. posib. dlia stud. ta vikl. vishchykh navch. zakladiv [Technique of organizing research work: textbook for students]. Kyiv: Forum [in Ukrainian].

2.Bondar, V.I. (1996). Didaktika: efektivni tekhnologii navchannia studentiv [Didactics: efficient technologies of teaching students]. Kyiv [in Ukrainian].

3.Krushelnytska, O.V. (2003). Metodologiia i organizatsiia naukovikh doslidzhen studentiv: navch. posib.[Methodology and organization of students' research work: textbook]. Kyiv: Kondor [in Ukrainian].

4.Navchalnii protses $u$ vishii shkoli: navch. posib. [Educational process at higher educational institution: textbook]. (2001). Kyiv: NPU im. M.P. Dragomanova [in Ukrainian].

\section{ЛІТЕРАТУРА}

1. Артемчук Г. І. Методика організації науководослідної роботи: навч. посіб. [для студ. та викл. вищих навч. закладів] / Г. І. Артемчук, В. М. Курило, П. М. Кочерган. - К. : Форум, 2000. - 271 с.

2.Бондар В. І. Дидактика: ефективні технології навчання студентів / В. І. Боднар. - К., 1996.- 140 с.

3. Крушельницька О. В. Методологія і організація наукових досліджень студентів : навч. Посіб / О. В. Крушельницька. - К. : Кондор, 2003. - 275 с.

4. Навчальний процес у вищій школі : навч. посіб. / За заг. ред. академіка О. Г. Мороза. - К. : НПУ імені М. П. Драгоманова, 2001. - 337 с.

5. Навчально-дослідна робота у вищих педагогічних навчальних закладах : навч.-метод. посіб. / Уклад. into the educational process contributes to the effective assessment of students' research skills and easier selection of highly-skilled students for research work. Its efficiency has been proved by the research outcomes. Besides, based on the carried out experiment involving 58 students we have selected 10 of them capable of research activities.

Further research work in this field is planned to involve elaborating the program for the development of talented Master-degree students' research skills at more profound level; as well as advancing the suggested technique for research skills assessment according to the specialty of Master-degree students, which would take into account the specificity of their major.

5.Navchalno-doslidna robota $u$ vishchikh pedagogichnikh navchalnikh zakladakh: navch.-metod. posib. [Research work at higher pedagogical instituions: textbook]. (2006). Glukhiv: RVV GDPU [in Ukrainian].

6.Sheiko, V.M., Kushnarenko, N.M. (2003). Organizatsiia ta metodika naukovo-doslidnitskoi diialnosti: pidruchnik [Organization and methods of research activities: textbook]. Kyiv: Znannia-Pres [in Ukrainian].

7. Cone, J. D. (1986). Idiographic, nomothetic, and related perspectives in behavioral assessment. In R. O. Nelson \& S. C. Hayes (Eds.): Conceptual foundations of behavioral assessment (pp. 111-128). New York: Guilford [in English].

8. Thomae, H. (1999). The nomothetic-idiographic issue: Some roots and recent trends. International Journal of Group Tensions, 28(1), 187-215 [in English].

: В. П. Зінченко, В. Б. Харламенко, І. М. Коренева. Глухів : РВВ ГДПУ, 2006. - 78 с.

6. Шейко В. М. Організація та методика науководослідницької діяльності : Підручник. / В. М. Шейко, Н. М. Кушнаренко. - 3-те вид., стер. - К. : ЗнанняПрес, 2003. - 233 c.

7. Cone, J. D. Idiographic, nomothetic, and related perspectives in behavioral assessment / J. D. Cone // In R. O. Nelson \& S. C. Hayes (Eds.): Conceptual foundations of behavioral assessment. - New York: Guilford, 1986. - C. 111-128.

8. Thomae H. The nomothetic-idiographic issue: Some roots and recent trends / H. Thomae // International Journal of Group Tensions. - 1999. - 28(1). - 187-215. 
Aніта Йосипівна Сікура, кандидат біологічних наук, професор кафедри медико-біологічних і валеологічних основ охорони життя та здоров'я, доиент, Національний педагогічний університет імені М. П. Драгоманова, вул. Пирогова, 9. м. Київ, Україна

Валерій Іванович Пліско, доктор педагогічних наук, професор кафедри педагогіки, психології та методики фізичного виховання, Чернігівський начіональний педагогічний університет імені Т. Г. Шевченка, вул. Гетьмана Полуботка, 53, м. Чернігів, Україна

Анна Сергї̈вна Балюк, аспірант кафедри педагогіки, завідувач інформаџійно-видавничого центру, Південноукраӥнський національний педагогічний університет імені К. Д. Ушинського, вул. Старопортофранківська, 26, м. Одеса, Украӥна

\section{ШЛЯХИ ВІДБОРУ СТУДЕНТІВ МАГІСТРАТУРИ ДО ДОСЛІДНИЦЬКОЇ РОБОТИ}

Педагогічні спостереження за процесом підготовки майбутніх професіоналів, аналіз їх продуктивної діяльності показав недостатність пізнавально-дослідного процесу при вивченні дисциплін, оволодіння знаннями i формування вмінь проводити наукові дослідження і неповну спрямованість на розвиток здібностей і мотивації до наукової діяльності у майбутніх фахівців. Виникає необхідність оцінювати майбутніх професіоналів за здібностями досягати кінцевого результату, вмінням використання різних прийомів, методів і методик організації та управління дослідженнями, наукової обробки даних, визначати і використовувати методи, прийоми, основні показники, отримані в ході дослідження тощо. Мета статті - розкрити механізм відбору студентів магістратури до дослідницької діяльності, а також шляхів підвищення їх мотиваційної зацікавленості в дослідницькій діяльності. Критеріями оцінювання за зовнішніми характеристиками були: ініціативність, творчість, алгоритм дій, точність, раціональність, правильні відповіді, пояснення. На основі вивчення відповідних складових поведінки студентів, їх знань і навичок було розроблено методику відбору майбутніх фахівців до дослідницької діяльності. Вона розрахована на диференційований підхід із залученням різних методів, способів визначення потенційних можливостей майбутніх фахівців до дослідницької діяльності і мотиваційного інтересу до цієї справи. Запропонована методика передбачає використання методів прямої дії, експертних оцінок та зворотного зв'язку, що можуть використовуватися як окремо, так і в сукупності відповідно до етапів. Поетапне використання зазначених методів сприяє ефективнішому оцінюванню здібностей студентів та якісному їх відбору до дослідницької діяльності. Запропоновану технологію було експериментально перевірено та підтверджено ії ефективність.

Ключові слова: дослідницька діяльність, творчість, студенти, оцінювання, розвиток.

Submitted on June, 26, 2017 